\title{
Structure of Complex Verb Forms in Meiteilon
}

\author{
Lourembam Surjit Singh \\ Centre for Advanced Studies in Linguistics, University of Delhi, Faculty of Arts, Extension Building, Delhi-110007, India \\ E-mail: 1surjit24@yahoo.com
}

Doi:10.7575/aiac.alls.v.7n.6p.46

URL: http://dx.doi.org/10.7575/aiac.alls.v.7n.6p.46
Received: 11/08/2016

Accepted: 02/10/2016

\begin{abstract}
This piece of work proposes to descriptively investigate the structures of complex verbs in Meiteilon. The categorization of such verbs is based on the nature of semantic and syntactic functions of a lexeme or verbal lexeme. A lexeme or verbal lexeme in Meiteilon may have multifunctional properties in the nature of occurrence. Such lexical items can be co-occurred together in a phrase as single functional word. Specifically, in the co-occurrences of two lexical items, the first component of lexical items has different semantic and syntactic functions in comparison to semantic and syntactic functions of the second component of lexical items. Such co-occurrences of two lexical items are the forms of complex verb that are covered with the term complex predicate in this work. The investigation in constructing complex predicate is thoroughly presenting in this work.
\end{abstract}

Keywords: Structures, complex verb, conjunct verb, compound verb, complex predicate

\section{Introduction}

Meiteilon belongs to a Tibeto-Burman family of languages mainly spoken in Manipur, Assam, Tripura, other neighbouring states of North East, India and some parts of Myanmar \& Bangladesh. The verbal category of Meiteilon is one of the major word classes in the language. The study of the structures of verbal categories and other complex verb forms will give important aspects in the field of linguistics. The complex verb forms which we have mentioned in this work will be an important domain which would help in revealing the functional properties of all verbal forms that have been existed in Meiteilon.

This paper investigates the framework of complex predicates and the structures of the formation of various complex verb forms in Meiteilon. Generally, there are different theoretical structures proposed by different scholars in the formation of complex verb forms. Specifically in Meiteilon, a verbal category can be classified into five sub-types such as 'simple or monomorphemic verbs' on the basis of monosyllabic and polysyllabic structures, 'complex verbs' on the basis of disyllabic and polysyllabic, 'compound verbs' on the basis of noun incorporation + verb and verb + verb coordinate compound, 'noun + verb' on the basis of noun dependent (clitic) or noun independent (non-clitic) and lastly 'reduplicated verbs' on the basis of reduplicated verbs-1 and reduplicated verbs-2 (Premabati 2008). The categorizations of the structures of these verbal sub-types are altogether based on syllabic structures and syllabification. Again, the category of complex verb forms have generally found to be put under the category of derived verbal roots (Premabati 2008). However, this paper proposes theory of 'complex predicate' as a framework of the study for revealing these all kinds of the forms of complex verbs in Meiteilon. The reason for representing the structures and forms of complex verb under the covered term 'complex predicate' is also justifying in detail in the theory of this work. It further tries to investigate how a combination of the formation of two lexical elements becomes complex verb forms and what kind of combinations of lexical elements are possible to form such complex verbs with different from the formation of simple verb and other forms of verbs in Meiteilon.

On the other hand, the issue of this study also have gone through the analysis of lexicalization and grammaticalization such as lexicalization processes to set phrases or in adding words or items to a lexicon whereas grammaticalization or de-lexicalization processes a word or lexeme into grammatical function or less grammatical to high grammatical element or lexical category to functional category, etc. In such process of delexicalization, a verbal lexeme can be semantically processed into functional word or affix and the function of such grammaticalized form of verb has different semantic and syntactic structures in the nature of occurrence. These different semantic and syntactic functional structures of a verb or co-occurrences of two or more verbs have been investigated within the framework of complex predicate, by putting the co-occurrences of two or more verbs together in a phrase within single linguistic unit. When these two verbal lexemes co-occur together as a single functional word it becomes a form of complex verb. Thus, a noun or an adjective and a verb can also co-occur together as a single functional word as another kind of complex verb form in the language. For making valid argument in the formation of such complex verb forms under the covered term complex predicate specifically for the constructions of compound verb and conjunct verb the various Meiteilon first hand data are presenting in this work as the examples of the formation of complex predicates.

Finally, the sections of this work organizes such as section-1 deals with introduction, section-2 discusses about the theories of complex predicates and complex verb forms, section-3 reveals the forms, functions and structures of 
conjunct verb under the covered term complex predicate, section-4 discusses about the semantic and syntactic functions of compound verb under the term complex predicate and section-5 concludes the work and submit the outcomes of this paper.

\section{Theoretical Background}

The major categories of lexemes in Meiteilon are noun and verb. Most of the lexemes are derived from these two major categories. From the roots of these two major word classes the other lexemes can also be formed in Meiteilon such as adjectives and adverbs. In the construction of the structures of lexemes in Meiteilon, the adjectives and adverbs do not have their own distinctive features. They are derived from nominal and verbal roots. For instance, adjectives derived from nouns, whereas adverbs derived from verbs. Hence, the structures of these two lexemes come under the subgroups of nominal and verbal roots. In case of the status of a morpheme, nouns or nominal roots may be in the forms of free and bound morphemes, whereas most of the verbs are in bound forms. In another case, if the verbal suffixes are attached with them the verbal root or verbal morpheme can be in the free form (Bhat \& Ningomba 1986, Chelliah 1997, Yashwanta 2000, Premabati 2008). The verbs in Meiteilon may further classify into three major categories such as action verb, state verb and process verb in case of simple verb forms (Bhat \& Ningomba 1986, Chelliah 1997). However, the verbs or simple verb forms that co-occur with other lexical elements to form single verbal phrase or single functional unit are considering as complex verb form in this work. These complex verb forms have been studied based on the structures of their construction namely conjunct verb, compound verb and small clauses/infinitival, by altogether they can be named as complex predicates. It has been called as Complex Predicate (CP), because complex predicate has a wide range of usage within a common framework. Complex predicates includes serial verbs, conjunct verbs, compound verbs and complex verbs which have formed by small clauses or infinitives.

By definition, a complex predicate (CP) is a grammatical category which is formed by combining some semantic features and co-occurrence of two or more lexical items (Kellogg 1875, Butt 1995, Das 2006, etc). These two lexical items of complex predicate can be two verbs as in the case of compound verbs. However, in the case of a conjunct verb one of the lexical items can be either a Noun or an Adjective and a light verb which hosts the Noun/Adjective to form the $\mathrm{CP}$. The co-occurrence of these two or more lexical items in complex predicate acts as a single linguistic unit. In the construction of complex verbs, two or more semantic features or co-occurrence of two or more lexical items combine together in which one of the lexical item acts as 'polar' (Hook 1974, 1991) and others items are combined as one then act as 'explicator' (Masica 1976, Abbi \& Gopalakrishnan 1992) or 'vector' (Hook 1974, 1991) or 'light verb' (Jespersen 1965, Mohanan 1994, Butt 1995) in case of compound verb, on the other hand, one of the lexical item acts as 'nominal host' or 'adjectival host' and others items are combined as one then act as 'light verb' (Jespersen 1965, Mohanan 1994, Butt 1995), in the case of conjunct verb. This light verb takes an object and the object takes a complement in some cases and finally becomes a verb which has a single verbal meaning like a simple verb does. In case of Meiteilon, this is a complex phenomenon which is still not fully understood when using complex verbs differencing from the already known term compound verbs. In this regard, Premabati (2008) categorized complex verbs on the basis of disyllabic and polysyllabic morphemes. Many derived verb forms have been explored on the basis of syllabification and de-lexicalization processes of verbal and nominal elements. But the question that must be asked regarding the formation of these complex predicates is that how the structures of syllabification or syllables can affect the construction of complex verbs? If this is not the case, the complex predicates must be classified on the basis of semantic and syntactic functions of the sequences of two or more lexical elements, as presenting in this paper.

\section{Conjunct Verbs in Meiteilon}

Conjunct Verbs (CNV) constructions are found in various South Asian languages such as in Hindi, Urdu, Bangla, Meiteilon, etc. The forms of this structure are primarily found either as Noun + Verb or Adjective + Verb combinations (Butt 1995). In conjunct verb construction, the light verb can take a host which could be a noun and adjective. In the following Meiteilon examples, the light verb takes a nominal, an adjectival and a derived noun as host respectively (as conjunct verb):

1. 'mipai thibə' 'afraid of'

$\begin{array}{llll}\text { thoiba } & \text { lan-gi } & \text { mipai } & \text { thi-re } \\ \text { thoiba } & \text { war-GEN } & \text { afraid-N } & \text { be ugly/fail-V-PERF }\end{array}$

'Thoiba afraid of war'.

2. 'nao khaibə’ be weaned'

$\begin{array}{lll}\text { sənbi-si } & \text { nao } & \text { khai-re } \\ \text { cow-3FS-PDET } & \text { small-N } & \text { separate-V-PERF } \\ \text { 'This cow has weaned (her calf/baby)' }\end{array}$


3. 'sərək sibə’ 'be intervened'

swai-se sərək si-re

here-PDET interval-N die-V-PERF

'Here is intervened'

4. 'khurəu thaybə' 'be hindered'

$\begin{array}{llll}\text { ləicin-si-nə } & \text { əijon-də } & \text { khurəu } & \text { thay-le } \\ \text { cloud-PDET-NOM } & \text { I-LOC } & \text { lock-N } & \text { carry-V-PERF }\end{array}$

'This cloud hindered me'.

As we see in (1), (2), (3) and (4) that the conjunct verbs are formed by putting either a noun or an adjective and a verb. In example (1) and (2), the light verbs 'thi' '-be ugly' and 'khai' '-separate, spread' take hosts which are adjectives 'mipai' '-afraid' and 'nao' '-small' and make conjunct verb form in the sentence. In example (3) and (4), the light verbs 'si' '-die' and 'thay' '-carry' take hosts which are nouns 'sərək' '-interval' and 'khurəu' 'lock' and make conjunct verb form.

In Meiteilon sequences like noun + verb and adjective + verb conjunct verb constructions, the noun and verb sequences are more productive the adjective and verb sequences. The table given below lists some light verbs that commonly used in conjunct verb constructions.

\begin{tabular}{|c|c|c|}
\hline \multicolumn{3}{|c|}{ Some Light Verbs that Commonly used in Conjunct Verb Construction in Meiteilon } \\
\hline cən 'be fitted' & $\mathrm{k}^{\mathrm{h}} \mathrm{a}$ 'to wall' & tou 'to do', tot 'to disconnect' \\
\hline ca 'to eat' & $\mathrm{k}^{\mathrm{h}} \mathrm{ay}$ 'to endure' & tek 'to break' \\
\hline cam 'to wash' & $\mathrm{k}^{\mathrm{h}} \mathrm{ai}$ 'to separate', 'to net' & ta 'to fall' \\
\hline həu 'to start' & $\mathrm{k}^{\mathrm{h}}$ oy 'to loud/noise' & ton 'to sit on something' \\
\hline hət 'to pinch or to beat/script' & $\mathrm{k}^{\mathrm{h}}$ oy 'to loud/noise' & $\mathrm{t}^{\mathrm{h}} \partial \mathrm{t}$ 'to release' or 'to put down' \\
\hline hei 'to know' & kou 'to call' & $\mathrm{t}^{\mathrm{h}} \mathrm{ek}$ 'to smash' \\
\hline hei 'to pour' & koi 'to round' & $\mathrm{t}^{\mathrm{h}} \mathrm{a}$ 'to release' or 'to put down' \\
\hline hou 'to rise/grow up' & lək 'to catch' & $\mathrm{t}^{\mathrm{h}} \mathrm{ay}$ 'to lift' \\
\hline hun 'to throw' & lou 'to take' & $\mathrm{t}^{\mathrm{h}} \mathrm{i}$ 'be ugly' or 'to search' \\
\hline ka 'to climb' & lay 'to noise' & $\mathrm{t}^{\mathrm{h}}$ ok 'to get out' \\
\hline kən 'to safe' & lei 'to live' & $\mathrm{t}^{\mathrm{h}}$ oy 'to cook' \\
\hline kai 'to break' & mən 'to make sarcasm' & $\mathrm{t}^{\mathrm{h}}$ uy 'to reach, encompass' \\
\hline kou 'to short/shortage' & sən 'to expand' & ja 'to agree' \\
\hline $\mathrm{k}^{\mathrm{h}}$ ən 'to screen' & sem 'to make' & jey 'to see' \\
\hline $\mathrm{k}^{\mathrm{h}}$ əy 'to know' & sum 'to lull, squeeze' & etc. \\
\hline
\end{tabular}

Figure 1. Some Light Verbs in Meiteilon

Out of these various examples of light verb, for investigating completely some of the sequences of verbal elements and formation of Meiteilon light verbs are illustrated in the following examples:

5. 'ikai khaybə' 'be endure of ashamed'

əi ikai -khay -i

I-1PS Shy-ADJ -endure-V-ASP

'I am feeling ashamed.'

6. 'khudi thibə' 'be stumbled'

$\begin{array}{llll}\text { əi-nə } & \text { ləikəy-də } & \text { khudi } & \text {-thi } \\ \text { I-1PS-NOM } & \text { surface-LOC } & \text { stumbling-N } & \text {-be ugly }\end{array}$

'I am stumbled on the surface'. 
7. 'netabə' 'be settled/stabled'

$\begin{array}{lll}\text { soni } & \text { ne } & \text {-ta-re } \\ \text { soni-3MS } & \text { Position-N } & \text {-lay/fall-V-PERF }\end{array}$

'Soni has settled' or 'Soni has stabled'

In example (5), the adjective 'ikai' '-shy' combines with the verb 'khay' '-endure' to express the sense of the verb '-to endure of ashame/be endurance of ashame', in (6), the noun 'khudi' '-stumble' combines with the light verb 'thi' '-be ugly' to form 'khudithi' '-stumble', and in example (7), the noun ne 'position' combines with the verb 'ta' '-fall' or 'lay' to form 'neta' '-be settled' or '-be stable' as a conjunct verb.

Another interesting point in the study of complex predicates is that all the sequences of noun + verb or adjective + verb forms cannot be considered as 'conjunct verb'. To say conjunct verb there are some parameters of the process of grammaticalization. In the process of grammaticalization, noun or adjective gets incorporated in the verb phrase in order to meet the requirement of maintaining the structural gap between the hosts and light verbs, and come up with a complete expression in the formation of complex predicates (Das 2009).

From the above studies, we can consider that the noun + verb conjunct can be divided into two types from the functional point of view i.e. (i) Free Lexical Noun + Verb (FLNV) and (ii) Reduced Form of Noun + Verb (RFNV).

\subsection{Free Lexical Noun + Verb Conjunct}

In this type of construction, a free lexical noun is always attached to the verb to form the conjunct verb in the language. Such types of conjunct verbs are very productive in Meiteilon. Here, the reason for classifying the first element of the conjunct verb as free lexical noun is because this noun can stand alone elsewhere in the sentence, it can also appear independently bearing complete nominal meaning in other constructions. However, when the verb occurs with a nominal host i.e. with a free lexical noun, it gives a grammaticalized meaning or that may slightly differ or may retain its own meaning. The reason for this is the noun that participates in the formation of the conjunct verb. Let us see the following examples in Meiteilon:

8. 'məka tabə' 'be sprouted (of spinach, mustard, arum plant etc.)'

$\begin{array}{lll}\text { kobi-si } & \text { moka } & \text {-ta-re } \\ \text { cabbage-PDET } & \text { leaf-N } & \text {-sprout.V-PERF }\end{array}$

'The cabbage (plant) has sprouted (leaves),'

9. 'səruk jaba' 'to participate' or 'to join' or 'to take a part'

sport-to $\quad$ oi-su $\quad$ səruk jai

sport-DAT I-also share-N -take-V-SAM

'I am also participated in the sport'.

10. ', səruk jenbə' 'to give or distribute one's share'

əi-gi səruk -jel-lo

I-1PS-GEN share $_{\mathrm{N}}$-distribute-V-IMP

'Distribute my share'

11. 'məha thabə' 'to deliver baby' or 'gives birth'

nəprum-adu məha -tha-re

eel-DDET baby-N -leave-V-PERF

'The eel gives birth'.

In example (8), 'məka' '-leaf' is a free lexical noun which combine with the light verb 'ta' '-fall' to express the sense of the conjunct verb 'məka tabə' '-sprouting (of spinach, mustard, arum plant etc.)'. In example (9), the free lexical noun 'səruk' '-share' combines with the light verb 'ja' 'take' and finally construct a conjunct verb 'səruk jabə' 'participate' in the sentence. Similarly, in (10), 'səruk' '-share' is a noun which again combines with the light verb 'jen' '-give' to express the meaning of 'səruk jenbə' '-to give or distribute one's share' in (10). And finally, the free lexical noun 'məha' '-baby' combines with the light verb 'tha' '-to give birth' and forms the conjunct verb 'məha thabə' '-to give birth a baby' which is also the case in (11) in Meiteilon. 


\subsection{Reduced Form of Noun + Verb Conjunct}

In this type of construction, the noun is always in reduced form i.e. dependent on the verbal element and it cannot occur independently or freely in the sentence bearing full or complete nominal meaning. In such construction the reduce form of noun is attached to a verb serving the meaning of the verb in the sentence. Hence, the verb itself cannot produce the desired meaning without the help of the reduce form of noun in the construction so as to retain its meaning as light verb. Let us see the following examples:

12. 'sarep phabə' 'be matured' or 'fully grown up'

$\begin{array}{lll}\text { ləi-si } & \text { sərep } & \text {-pha-re } \\ \text { flower-PDET } & \text { growth-N } & \text {-complete-V-PERF }\end{array}$

'This flower is fully grown up.

13. 'səra sənbə' 'be opened to all' or 'spread into air'

pao-du sora səl-le

news -PDET people-N -spread-V-PERF

'This news has been opened to all'.

14. 'nao pubə' 'be pregnant'

hui-si nao -pu-re

dog-DDET baby-N -bear-V-PERF

'This dog is pregnant'.

15. 'tora tubə' 'fall sick in a mass'

$\begin{array}{llll}\text { dengu-nə } & \text { miyam-se } & \text { tora } & \text {-tu-re } \\ \text { dengue-NOM } & \text { people-DET } & \text { mass-N } & \text {-fall sick-V -PERF }\end{array}$

'These people have fallen sick from dengue'.

In example (12-15), the reduced forms of nouns such as 'sarep' '-grow', 'səra' '-people', 'nao' '-baby' and 'tora' 'mass', combines with the light verbs 'pha' '-complete', 'səl' '-spread', and 'tord' '-fall' or '-collapse' formed conjunct verbs constructions. In case of these reduced forms of nouns when the light verbs are not combined with these nominals, these all verbal words have different word classes bearing different meanings. But the light verbs alone cannot produce desired meanings of conjunct verbs. Same to the light verbs, the reduce form of nouns also cannot produce full nominal meanings and cannot even occur alone without any verbal elements in the language. So, it becomes a reduced form of noun in the constructions. Hence, the complete desired meaning of a conjunct verb can produce only after this reduced form of noun and light verb are co-occurred in sharing their semantic and syntactic features in Meiteilon.

Thus, in (12), without the reduced form of noun 'sarep' '-growth', the occurrence of the verb 'pha' '-to complete' only produced the meaning in the sentence as "nupi əsi phare" it sounds the meaning as "-the girl is eloping forcefully (by someone)" or "The girl is being arrested" or "the girl is arrested". However, in the example of (12), (13), (14) and (15), all the reduced form of nouns are grammaticalized and semantically bleached before they are added to the verbs and form conjunct verbs in Meiteilon. It reveals that either the light verb or reduced form of noun alone cannot give desire meaning of the conjunct verb, unless there are co-occurred in the sequences like noun + verb sequences take place to form conjunct verbs in Meiteilon.

\subsection{Adjective + Verb Conjunct}

Meiteilon adjectives are derived from nominal and verbal roots, nouns and verbs are the only major lexemes in Meiteilon (Bhat \& Ningomba 1986, Chelliah 1994, 1997, and Thoudam 1980). The Meiteilon Conjunct Verbs which are in the sequences of Adjectives and Verbs are not productive as Noun and Verbs Conjunct. The constructions of adjectival derivational compounds like verbal or nominal derivational adjectives are quite productive but these are not in the status of conjunct verbs. The following are the examples of Adjective + Verb conjunct in Meiteilon.

16. 'phəjə thokpə' 'become glowed'

məhak phəjə -thok-le

she-3FS beautiful-Adj. -exit-V-PERF

'She (her face) becomes glow' or 'She becomes beautiful'. 
17. 'wakai naybə' 'speaking harmful word' wakai yay-nu harmful word-Adj. speak-V-PROH 'Don't speak harmful word'.

18. 'wathi subə' 'speaking useless word' əi-khoi wathi su-ri we-1PS-PL useless word-Adj. work-V-PROG

'We are speaking useless word' or 'We are speaking non-sense'.

In example (16), the adjectives 'phəłə' '-beauty', 'wakai' '-harmful word' in (17) and 'wathi' '-useless word' in (18) take the light verbs 'thok' '-exit', 'yay' '-speak", and 'su' '-work". The adjectives are the hosts and they are delexicalized and bleached their meanings to the light verb and light verb takes all inflectional markers. When these two lexical elements co-occur in a single linguistics unit the light verb become the syntactic head of the verbal compound. In the process of grammaticalization the adjectival hosts lose their lexical meanings and contribute all semantic functions for the light verbs to form conjunct verb in Meiteilon.

\section{Compound Verbs in Meiteilon}

In the construction of verb-verb compound, the first component of the verb functions as a polar $\left(\mathrm{V}_{1}\right)$ where the second component of the verb functions as an 'explicator' $\left(\mathrm{V}_{2}\right)$ (Masica 1976, Abbi \& Gopalakrishnan 1992) or 'light verb' (Jespersen 1965, Mohanan 1994, Butt 1995). The semantic and morphological function of $\mathrm{V}_{2}$ is quite important and takes crucial role to construct compound verb in Meiteilon. This second component of the verbal compound is semantically delexicalized and bears all grammatical inflections such as tense, mood or aspect of the sentence (Hook 1974). In such co-occurrences, all the sequences of verbal elements are not considered as compound verb, unless the two or more verbal elements co-occur in a single linguistic environment by sharing their semantic and syntactic properties in a mono-clausal formation. Specifically in Meiteilon, a verb may have three categories such as action verb (directional \& non-directional action verbs), state verb and process verb. The compound verb that is formed $\mathrm{V}_{2}$ with the sequences of a directional verb and a deictic verb is hardly found in the language, but if a directional verb co-occurred with a deictic or verbal deictic or deictic particle it may form another kind of simple verb form that indicates directions of an event. However, if this directional verb co-occurs with other categories of verbs such as state and action verbs, in the position of $\mathrm{V}_{2}$, the function of $\mathrm{V}_{2}$ may have capacity to occur as an explicator $\left(\mathrm{V}_{2}\right)$ in the clause. Such category of occurrences has been termed as 'directional light verb' in first case, 'lexical $V_{2}$ directional' in second case (Butt 2003: online update version) and this class of second case of verb has often been referred to as "phase" complements (Chao 1968). The directional light verb may further distinguish clearly from other lexical $\mathrm{V}_{2}$ directional (deictic) usage and this directional light verb may also further distinguish from a fully aspectual (inflectional aspect marker) usage through a number of differing diagnostics (Scott 1996) ${ }^{1}$. This case of the co-occurrences of a verb and a 'lexical $\mathrm{V}_{2}$ directional' may have in the case of Meiteilon. Because of the directional verb which is occurred in the position of explicator $\left(\mathrm{V}_{2}\right)$ has highly productive by its characteristics, while co-occurring with other main verbs. Such condition of the occurrences of directional explicator or light verb has also been existed in Mandarin Chinese. In a critical example in Mandarin Chinese, it also provides evidence that exist such set of light verbs which are indentified by a set of distinct properties such as phonological, semantic and syntactic properties (Butt \& Scott 2002). However, such condition is not applicable for all the directional light verbs or directional explicators in Meiteilon as well as in Mandarin Chinese. Let us take the following Meiteilon examples for investigating how various forms of $\mathrm{V}_{1}$ and $\mathrm{V}_{2}$ function in constructing compound verb:

19. * 'kaothokpə' 'to kick out'

$\begin{array}{lll}\text { bol-do } & \text { kao } & \text {-thok-le } \\ \text { ball-DDET } & \text { kick-V } & \text {-out-Affix-PERF }\end{array}$

'The ball has kicked out'.

20. 'kaot ${ }^{\mathrm{h}}$ okpə' 'to forget'

mohak $\mathrm{t}^{\mathrm{h}}$ əbək-to kao $\quad-\mathrm{t}^{\mathrm{h}}$ ok-le

he-3PS work-DDET forget $-V_{1}$-exit- $V_{2}$-PERF-ASP

'He has forgotten the work'.

${ }^{1}$ Scott (1996) proposes a diagnostic device for the categorization of directional verb. He devides the category of directional verbs into four ways such as (i) usage of main verb, (ii) usage of verb second $\left(\mathrm{V}_{2}\right)$ directional, (iii) usage of aspectual (experiential perfect) and (iv) it is very similar to the usage of directional $\mathrm{V}_{2}$ and the aspectual use, but clearly identifiable syntactic and phonological differences. For instance, through this device he distinguishes the light verb clearly from the lexical $\mathrm{V}_{2}$ directional usage in first case, and he also distinguishes a light verb from a fully functional aspectual usage via a number of differing diagnostics in second case i.e. completely summarized into three phases of test under various distributions of \pm tones. 
In the above example (19), the asterisk marker '*' indicates the construction of non-compound verb, there is an object 'bol' '-ball' and sequences of verbs 'kao' -'kick', 'thok' '-exit' and '-le' '-perfect aspect marker' in the sentence. In this sequence of verb-verb occurrences, the first component of the verb 'kao' '-kick' is a directional action verb and also a 'verbal root', whereas, the second component of the verb 'thok' '-exit' is an affix that occurs as the first level derivational suffix along with the word order of second level derivational suffix 'le' perfective marker in the clause. As the verb 'thok' '-exit' is a verbal deictic or suffix there is no verb-verb compound construction in the clause. As the verb 'thok' -'exit' is highly grammaticalized it has no capacity to occur as an explicator verb, though this construction is the co-occurrences of two verbs in a clause. When such verbal element is highly grammaticalized the stem becomes affix or deictic element in the process of grammaticalization, therefore, such verbal element is able to occur only as an affix or verbal deictic bearing directional meanings only in compounding the lexemes. So, there is no such case of possibility for co-occurring two directional verbs together in single verbal phrase to form a compound verb in the language. In other condition, when such second verbal element co-occurred after a directional verbal root the general productivity of the process of grammaticalization is an 'affix' or 'aspectual marker' in most of the cases (Butt \& Scott 2002). If it has co-occurred after an action or state verb it may have the functional capacity as adverbial, aspectual, infinitival or small clauses for occurring in the conditions of 'explicator' or 'light verb' in the language.

On the other hand, the occurrences of both the verbs 'kao' '-kick' and 'kao' '-forget' in (19) and (20) are tonal words. But, in example (20), there is an agent 'məhak' '-he', accomplished action 'thəbək' -'work' and sequences of action verbs 'kao' '-forget' and 'thok' '-exit' in the clause. The verb 'kao' '-forget' is a stative verb that functions as polar verb and the verb 'thok' '-exit' is an action verb that functions as explicator verb in the sentence. Here, the verb 'thok' '-exit' is occurred with a stative verb and occurs like an aspectual explicator contrasts to the deictic and other resultatives verb do, and also not having the sense of verbal deictic in the context of vertical and horizontal space in the clause. It is less grammaticalized and semantically delexicalized while co-occurring with polar verb. It is functionally more productive than in the case of the occurrence of example (19) and also has capacity to occur as functional word through the process of grammaticalization. As the verb 'thok' '-exit' has multiple functional capacity we cannot generalize the category of such verbal element neither as an affix nor as a verbal lexeme in the constructions of complex predicates in Meiteilon.

21. 'houdokpə' 'to wake someone up'

$\begin{array}{llll}\text { məhak } & \text { əi-nə } & \text { həu } & \text {-dok-i } \\ \text { he-3PS } & \text { I-NOM } & \text { wake--V } & \text {-exit-V } 2-S A M\end{array}$

'I wake him up'.

22. * 'həugətpə' 'rise up' or 'get up'

məhak tum-bə həu -gət-le

he-3PS sleep-NML wake. $\mathrm{V}_{1}$-up-PERF

'He has woken up' or 'He has risen up (from sleeping)'.

23. * 'tum həubə' 'be started sleeping'

məhak tum -həu-re

he-3PS sleep- $V_{1}$ start-ASP-PERF

'He has started sleeping'.

In example (21), in the sequences of verbs 'həu' '-rise' or '-wake' and 'dok' '-exit', the first component of the verb 'həu' '-rise' or '-wake' functions as a 'polar' or 'main verb' when another verb 'dok' '-exit' functions as an 'explicator' in the clause. In the co-occurrence of these two verbal elements the 'həu' '-rise' or '-wake' carries the core meaning of the compound verbal phrase while other verb explicates its meaning and grammaticalized as functional meaning and takes perfect aspect marker '-re' '-PERF' and finally form 'həudokpə' which means '-to wake someone up' in the clause. Here, the explicator takes crucial role in constructing the above compound verb in which the explicator 'dok' 'exit' reduces its full lexical meaning, it semantically construct functional meaning and becomes the adverbial meaning ${ }^{2}$ that produce a kind of benefactive meaning like the action is made for someone or other benefactive in the clause (Abbi \& Gopalakrishnan 1991).

In example (22), the asterisk marker ' $*$ ' indicates the construction of non-compound verb form. Though it is the sequences of two verbal elements, the second component of the verbal element is a deictic which expresses horizontal 
direction of the action in the clause. On the other hand, there is a subject 'məhak' '-he', accomplished argument 'tumbə' '-sleep', with '-bə' '-NML' marker and a main verb 'həu' '-rise' or '-wake' followed by a deictic '-gət' '-up' as a suffix in the sentence. Not further semantic and syntactic arguments found in with the deictic '-gat' '-up' for the main verb.

In example (23), again the asterisk marker '*' indicates the construction of non-compound verb form. There is a subject 'məhak' '-he', the main verb 'tum' '-sleep' and an aspectual element 'həu' '-start' of an event' or 'stated of an event' or 'already become of an event'. This aspectual element 'həu' '-start' may further expresses the meaning of which an action processes of 'the beginning an event before the ending of another event' in Meiteilon. Therefore, such aspect marker can be generally named as 'inchoative aspect marker' in this work with reference to the works of Bath (1995) and Traugott (2010).

24. ('jarekpə' 'to stay' or 'to sleep' (at a place))

$\begin{array}{llll}\text { rafu } & \text { ləusən-də } & \text { ja } & \text {-rek-i } \\ \text { raju } & \text { farmhouse-LOC } & \text { sleep- } V_{1} & \text {-stay- } \mathrm{V}_{2}-\mathrm{SAM}\end{array}$

'Raju sleeps at farmhouse' or 'Raju stays at farmhouse'.

In example (24), there is an agent 'rafu' '-Raju' and an object 'ləusəy' '-farmhouse' and sequence of action verbs 'ja' '-sleep' which is an intransitive and 'rek' '-stay' ('lek' changed into 'rek' as per phonetic rules of the language) which is also an intransitive verb in the sentence. The verb 'ja' '-sleep' functions as polar, while the verb 'rek' '-stay' functions as an explicator and takes all inflectional markers. When these two intransitive verbs co-occur in a sequence both the verbs contribute semantically equal meanings, neither polar nor explicator can appear in a single functional environment bearing the desired meaning of the compound verbal phrase. In the co-occurrence, though the polar bears the core verbal meaning of the compound verb construction, the polar ' $j a$ ' '-sleep' is itself a dependent form of verb that syntactically occur in a root form, but can't occur independently elsewhere in the sentence. In other sense, the explicator 'rek' '-stay' contributes highly productive meaning and also retains its lexical meaning while constructing compound verb in the sentence. However, in compounding the verbal meaning of explicator is grammaticalized and semantically bleached its meaning and occurring in stem form after the polar verb. Altogether, these co-occurrences of two verbs mutually shared all its semantic and syntactic features in constructing 'jarek' 'to stay' or 'to sleep' in CP in Meiteilon.

\section{Conclusion}

The paper has investigated a differing complex verbs or complex verb forms under the covered term complex predicate. All kinds of complex verbs that are formed with the combinations of two or more lexical elements which jointly predicate within a single functional word or linguistic unit are the forms of broader term 'complex predicate' in Meiteilon. The paper revealed that the explicator took crucial roles to construct complex predicate in a clause. Generally, all the explicators have capabilities to occur as lexemes elsewhere in the sentence or clause as they have multiple functional properties, but when such lexemes functioned as explicators it semantically delexicalized and explicates its lexical meaning to the polar in most of the occurrences. The forms and functions of an explicator in Meiteilon can't be generalized; capability of the functions of a lexeme is specific in forming a specific CP. The polar carries core verbal meaning, whereas the explicator carries all inflectional markers of the complex predicate in Meiteilon. The formation of $\mathrm{CP}$ consists of the constructions of conjunct verb and compound verb in the language.

\section{References}

Abbi, A. (1991). Semantics of explicator compound verbs: in South Asian languages. Language Sciences 13.2: 161-180

Abbi, A. (1992). The explicator compound verb: some definitional issues and criteria for identification. Indian Linguistics 53, 27-46.

Abbi, A., and Gopalakrishnan, D. (1992). Semantic typology of explicator compound verbs in South Asian languages. Paper restricted online.

Alsina, A. (1996). Complex Predicates: Structure and Theory. Stanford: CSLI Publications.

Alsina, A., Bresnan, J., and Sells, P. (ed.) (1997). Complex Predicates. Stanford: CSLI Publications.

Baker, B., and Harvey, M. (2010). Complex Predicate Formation. In Complex Predicates: Cross-linguistic Perspectives on Event Structure, Mengistu Amberber, ed. Brett Baker and Mark Harvey. Cambridge: Cambridge University Press.

Begum, R. et al. (2011). Identification of conjunct verbs in Hindi and its effect on parsing accuracy. Cycling: Sciweavers.

Bhat, D.N.S. and Ningomba, M.S. (1995). Manipuri Grammar. Central Institute of Indian Languages, Mysore.

Bhat, D.N.S. and Ningomba, M.S. (1995). Manipuri Grammar. Mysore: CIIL. 
Butt, M., and Jessica. D. (1993). Conscious choice and some light verbs in Urdu. Complex Predicates in South Asian languages, ed. by M. K. Verma, Manohar Publishers and Distributors: New Delhi.

Butt, M. (1994). Complex Predicate Scrambling in Urdu. In Theoretical Perspectives on Word order in South Asian Languages, ed. Miriam butt, Tracy Holloway King, and Gillian Ramchand. Stanford, California: CSLI Publications.

Butt, M. (1995). The structure of complex predicates in Urdu. Stanford, California: CSLI Publications.

Butt, M., and Wilhelm, G. (2001). On the (Semi) Lexical Status of Light Verbs. In Semi-lexical Categories: On the Content of function words and the function of content words, ed. Norbert Cover and Henk van Reimsdijk. Berlin: Mouton de Gruyter.

Butt, M., and Biljana, S. (2002). Chinese Directionals. Talk given as part of the Workshop Complex Predicates. Particles and Subevents, Konstanz, September.

Butt, Miriam and Gillian Ramchand. (2003). Complex Aspectual Structure in Hindi/Urdu. In The Syntax of Aspect, ed. Nomi Ertishik-Shir and Tova Rappaport. Oxford: Oxford University Press.

Butt, M. (2010). The Light Verb Jungle: Still Hacking Away. In Complex Predicates: Cross-linguistic Perspectives on Event Structure, Mengistu Amberber, ed. Brett Baker and Mark Harvey. Cambridge: Cambridge University Press.

Chao, Y.R. (1968). A Grammar of Spoken Chinese. Berkeley, California: The University of California Press.

Chelliah, S. L. (1997). A Grammar of Meitei. Mouton De Gruyter, Berlin: New York.

Choi, Seongsook. 2005. Multiple Verb Constructionsin Korea. Doctoral Dissertation, University of Sussex.

Das, P. K. (2006). Grammatical Agreement in Hindi-Urdu and its Major Varieties. Munchen: Lincom Europa.

Das, P. K. (2015). The linguistic prerequisites and grammaticalization of 'compound verb' in Hindi. Journal of Sotuh Asian Studies, HUFS, South Korea.

Das, P.K. (2009). Forms and function of conjunct verb construction in Hindi, Journal of South Asain Studies, HUFS, South Korea.

Hook, P.E. (1974). The Compound Verb in Hindi. Center for South and Southeast AsianStudies: The University of Michigan.

Hook, P. E. (1993). Aspectogenesis and the Compound Verb in Indo-Aryan. In Complex Predicates in South East Asian Languages, ed. Manindra Verma. Delhi: Manohar Publishers \& Distributors.

Kellogg, S. (1875). Grammar of the Hindi language. London: Routledge.

Masica, C. (1976). Defining a Linguistic Area: South Asia. Chicago: The University of Chicago Press.

Mohanan, Tara. (1994). Argument Structure in Hindi. The Stanford University Press.

Paul, S. (2004). An HPSG account of Bangla compound verbs with LKB implementation. [Ph.D. Dissertation], University of Hyderabad, Hyderabad.

Premabati, B. (1998). Affixation. Working Paper Series. Imphal: Language Cell, Directorate of Education (S), Government of Manipur.

Premabati, B. (2008). The Syntax of Manipuri Verbs. PhD Dissertation, Manipur University.

Scott, Biljana. (1996). Aspectogenesis and the Categorisation of Directionals in Chinese. Doctoral Dissertaion, Oxford University.

Thoudam, P. Ch. (1980). Grammatical Sketch of Meiteilon [Unpublished Ph.D Dissertation]. Jawaharlal Nehru University: New Delhi.

Verma, M. K. ed. (1993). Complex Predicates in South Asian Languages. Manohar Publisher and Distributor: New Dehi.

Yashwanta Singh, Ch. (2000). Manipuri Grammar. Rajesh Publication: New Delhi.

\section{Abbreviations}

$\begin{array}{lll}\text { Meiteilon } & \text { ABB } & \text { Terminology } \\ \text { tu/to/do/ədu } & \text { DDET } & \text { Distal Determiner } \\ \text { də/tə } & \text { DAT } & \text { Dative } \\ \text { də/tə } & \text { DEC } & \text { Decorative } \\ \text { də/tə } & \text { LOC } & \text { locative } \\ \text { ke/ge } & \text { OPT } & \text { Optative } \\ \mathrm{i} & \text { SAM } & \text { Simple Aspect Marker } \\ & \text { ASP } & \text { Aspect Marker } \\ \text { ki/gi } & \text { GEN } & \text { Genitive } \\ \text { re/le/lə } & \text { PERF } & \text { Perfective }\end{array}$




$\begin{array}{lll}\text { li } & \text { PROG } & \text { Progressive } \\ \text { nə } & \text { NOM } & \text { Nominative } \\ \mathrm{pu} / \mathrm{bu} & \text { ACC } & \text { Accusative } \\ \mathrm{pə} / \mathrm{b} ə & \text { NML } & \text { Nominalizer } \\ \mathrm{se} / \mathrm{si} & \text { PDET } & \text { Proximate Determiner } \\ \mathrm{sin} / \mathrm{cin} & \mathrm{IN} & \text { Inward } \\ \text { thok/tok/dok } & \text { OUT } & \text { Outward } \\ \text { thə } & \text { DOWN } & \text { Downward } \\ \text { khət/gət } & \text { UP } & \text { Upward } \\ & \text { 1PS } & \text { First Person Singular } \\ & \text { 3PS } & \text { Third Person Singular } \\ & 3 P P & \text { Third Person Plural } \\ & 3 \mathrm{MS} & \text { Third Person Masculine Singular } \\ & \text { 3FS } & \text { Third Person Feminine Singular } \\ & \text { FS } & \text { Feminine Singular } \\ & \text { MS } & \text { Masculine Singular }\end{array}$

